\title{
Neuroinflammation and excitatory symptoms in bipolar disorder
}

\author{
Isabella Panaccione ${ }^{1,2,3}$, Gianfranco Spalletta ${ }^{2,4}$, Gabriele Sani ${ }^{1,2,3}$ \\ ${ }^{1}$ Department of Neuroscience, Mental Health and Sensory Organs, School of Medicine and Psychology, Sapienza University of Rome, \\ Sant'Andrea Hospital, 00189 Rome, Italy. \\ ${ }^{2}$ Department of Clinical and Behavioural Neurology, Neuropsychiatry Laboratory, IRCCS Santa Lucia Foundation, O0179 Rome, Italy. \\ ${ }^{3}$ Centro Lucio Bini, 00193 Rome, Italy. \\ ${ }^{4}$ Menninger Department of Psychiatry and Behavioral Sciences, Beth K and Stuart C Yudofsky Division of Neuropsychiatry, Baylor \\ College of Medicine, Houston, TX 77030, USA
}

\section{A B S T R A C T}

Neuroinflammation has been proposed as a strong biological factor underlying the development of neuropsychiatric diseases. A role for dysregulation of the immune system was initially suggested in depressive disorders and subsequently extended to other illnesses, including bipolar disorder (BD). Indeed, there is growing evidence confirming the presence of a generalized pro-inflammatory state in BD patients, involving alterations in cytokine, acute-phase proteins, and complement factor secretion, white blood cell differentiation, microglial activation, arachidonic acid signaling pathways, and increased oxidative stress markers. Medications commonly used to treat BD, such as lithium, antiepileptics and antipsychotics, show some immunoregulatory activity both in vitro and in vivo. The aim of our study was to review the role of different inflammatory mechanisms, specifically in the development of excitatory symptoms, via a systematic PubMed search of the literature. Despite the high variability of results among studies, we found evidence indicating specific alterations of the inflammatory response during manic and mixed states of $\mathrm{BD}$. These findings may help to clarify some of the complex mechanisms underlying the development of excitatory symptoms and suggest a potential role for drugs targeting the inflammatory system as new therapeutic options.

Key words: Anti-inflammatory drugs, bipolar disorder, glia, interleukin, mania, mixed states, neuroinflammation

\section{INTRODUCTION}

Amongst the wide constellation of factors thought to be involved in the pathophysiology of mental illness, there's accumulating evidence for a pivotal role of the inflammatory system as a risk factor for neuropsychiatric disease onset and progression. ${ }^{[1-3]}$ In the early 1970s, several studies showed how the brain is able to modulate the immune system, focusing on the role of stress and associated hypothalamus-pituitary axis mechanisms. These observations have been translated in studies

Corresponding Author: Dr. Gabriele Sani,

Department of Neuroscience, Mental Health and Sensory

Organs, School of Medicine and Psychology, Sapienza

University of Rome, Sant'Andrea Hospital, Via di Grottarossa,

1035/39, 00189 Rome, Italy.

E-mail: gabriele.sani@uniroma1.it

\begin{tabular}{|c|c|}
\hline \multicolumn{2}{|c|}{ Access this article online } \\
\hline Quick Response Code: & \\
\hline$\square$ & $\begin{array}{l}\text { Website: } \\
\text { www.nnjournal.net }\end{array}$ \\
\hline & $\begin{array}{l}\text { DOI: } \\
\text { 10.4103/2347-8659.167304 }\end{array}$ \\
\hline
\end{tabular}

involving patients diagnosed with the major depressive disorder. Indeed, both the clinical observation of high rates of depressive symptoms in patients affected by immune-related diseases, such as cancer, diabetes, and cardiovascular, inflammatory, and autoimmune diseases, and the results of a majority of studies investigating the role of inflammation in depressive disorders confirmed this hypothesis. ${ }^{[4,5]}$ The link between depressive symptoms and systemic inflammation is strengthened by the experimental observation that the injection of interleukin (IL)- $1 \beta$ or tumor necrosis factor (TNF)- $\alpha$ in animals produces a range of behavioral abnormalities known as "sickness behavior". Mice show reductions in locomotor activity, social interaction, novelty seeking behavior, saccharine preference, brain self-stimulation, and food and water intake, as well as impairments in learning and memory ${ }^{[6-8]}$

This is an open access article distributed under the terms of the Creative Commons Attribution-NonCommercial-ShareAlike 3.0 License, which allows others to remix, tweak, and build upon the work non-commercially, as long as the author is credited and the new creations are licensed under the identical terms. For reprints contact: nn_editor001@nnjournal.net

Cite this article as: Panaccione I, Spalletta G, Sani G. Neuroinflammation and excitatory symptoms in bipolar disorder. Neuroimmunol Neuroinflammation 2015;2:215-27.

Received: 06-04-2015; Accepted: 05-05-2015 
In humans, treatment with interferon (IFN)- $\alpha$ induces depressive symptoms such as anhedonia, fatigue, suicidal thoughts, cognitive impairments, loss of appetite, and sleep alterations, ${ }^{[9,10]}$ therefore hinting that IFN- $\alpha$ may contribute to the development of mood disorders. ${ }^{[11,12]}$ Healthy volunteers injected with Salmonella abortus equi endotoxin show increased circulating levels of inflammatory mediators and develop psychiatric symptoms, such as anxiety and depressed mood, as well as mild, transient cognitive impairments. ${ }^{[13]}$ Depressed patients with no other concomitant medical conditions show alterations in the levels of many pro-inflammatory cytokines and acute-phase proteins, both in peripheral blood and cerebrospinal fluid (CSF). ${ }^{[14]}$ In particular, variations in the concentration of IL-1, IL-6, TNF- $\alpha$, and C-reactive protein (CRP) have been observed in patients diagnosed with depressive disorders when compared to healthy controls. ${ }^{[15-20]}$ Glial abnormalities, ${ }^{[21-23]}$ increased oxidative stress, ${ }^{[24-27]}$ macrophage activation, ${ }^{[28-30]}$ and alterations in the arachidonic acid (AA) signaling cascade ${ }^{[31-35]}$ have also been described in depressed patients. Taken together, these results confirm the substantial involvement of the immune system in the mechanisms of depressive disorders, possibly via interactions between the immune system and the neuroendocrine and autonomic nervous system. ${ }^{[36-40]}$

Starting from these observations, the role of the immune system has been investigated in other neuropsychiatric diseases, including bipolar disorder (BD), schizophrenia, anxiety disorders, and personality disorders. A chronic inflammatory state that exacerbates during symptomatic relapses has been suggested to be involved in the pathophysiology of BD. ${ }^{[41]}$ Interestingly, therapy with IFN- $\alpha$ has been reported several times to induce manic/hypomanic or mixed states in nonpsychiatric patients. ${ }^{[42-45]}$ One study highlighted the higher prevalence of mild excitatory symptoms (i.e. irritable mood, racing thoughts, distractibility, agitation, and insomnia) associated with anhedonia and fatigue in IFN- $\alpha$ treated patients, rather than typical major depressive or euphoric symptoms. ${ }^{[46]}$ Another study found that nonpsychiatric patients are more likely to develop depressive symptoms following a therapy with IFN- $\alpha$ if they experienced lifetime subthreshold manic/ hypomanic symptoms. ${ }^{[47]}$ Similarly to what has been observed in depression, there is a high rate of comorbidity between BD and other inflammation-related medical conditions, such as diabetes, metabolic syndrome, and cardiovascular and cerebrovascular diseases, ${ }^{[48-50]}$ which led some authors to question if BD could be considered as a multi-system inflammatory illness. ${ }^{[11]}$

Many studies conducted on BD patients have demonstrated increased levels of pro-inflammatory markers, both in the blood and in the brain, that is, abnormal T-cell and monocyte-macrophage activation, alterations in chemokine, cytokine, prostaglandin, and acute-phase protein synthesis, aberrant inflammatory-related gene expression, increased oxidative stress markers, and microglial activation. ${ }^{[28,52-67]}$ The vast majority of studies focused on assessing peripheral cytokine levels. Despite some mixed results, globally $\mathrm{BD}$ patients show higher serum concentrations of TNF- $\alpha$, soluble TNF-receptor 1 (sTNF-R1), IL-1 $\beta$, IL-4, soluble IL-2 receptor (sIL-2R), and sIL-6 receptor (sIL-6R) compared to healthy controls, as well as a nearly-significant trend for IL-6. ${ }^{[54,68-70]}$ These results refer to both euthymic and symptomatic BD patients and do not emphasize the possible differences in the cytokine expression patterns correlated with the presence of excitatory symptoms. We, therefore, performed an analysis of the literature aimed at highlighting the possible presence of alterations in immune system activity, specifically in relation to excitatory symptoms of BD. We also briefly examined the possible use of anti-inflammatory drugs as add-on therapies to improve clinical outcomes.

We performed a literature review through a careful search of articles using PubMed. We conducted an initial search using keywords such as "affective disorder" or "major depression" or "bipolar dis*" and "inflammat*" to provide context. Subsequent searches were performed using the following key words: "bipolar dis*" and/or "mania" or "manic" or "mixed" or "depressi*”, cross-referenced with a set of inflammation-related terms, such as "cytokine", "IL", "glia", "oxidative stress", and "AA". To examine the role on the immune system of drugs commonly used to treat excitatory symptoms, we cross-referenced the above-mentioned set of inflammatory-related keywords with "lithium", "mood-stabilizing agents", and "antipsychotics". Finally, to identify studies on the possible role of anti-inflammatory drugs in the management of affective episodes, we cross-referenced the mood-related keywords mentioned earlier with the terms "anti-inflammatory drugs", "coxib” and "anti-TNF- $\alpha$ ".

Reference lists from selected papers were subsequently searched to identify further relevant literature. We limited the search to papers written in English. There were no timeframe limitations in our searches. Data on alterations of the inflammatory system in excitatory phases of BD (mania, hypomania and mixed states) are presented together because most of the studies do not specifically differentiate between the three. 
IMMUNE SYSTEM ALTERATIONS AND EXCITATORY SYMPTOMS IN AFFECTIVE DISORDERS

Inflammation in manic, hypomanic and mixed states Cytokines are low-molecular-weight proteins secreted by immune cells, such as white blood cells and microglia, which play a crucial role in modulating the inflammatory response. In the brain, cytokines exert immune protection by promoting the elimination of damaged neurons and have also been demonstrated to influence neurogenesis and cell survival. ${ }^{[71]}$ However, dysregulation of cytokine synthesis and activity is known to lead to alterations of synaptic transmission and synaptic plasticity, neurotoxicity, and neuronal death. ${ }^{\left[{ }^{[3}\right.}$

An imbalance between pro- and anti-inflammatory cytokines has been suggested to exist in manic patients versus healthy controls, ${ }^{[72]}$ underlying a more pronounced shift toward a pro-inflammatory status in acute relapses. There is also evidence of an imbalance between cytokines secreted by type $1 \mathrm{~T}$ helper (Th1) lymphocytes and type $2 \mathrm{~T}$ helper (Th2) lymphocytes during mania, with an increased Th1/Th2 ratio that normalizes after treatment. ${ }^{[73]} \mathrm{IL}-1 \beta$ levels are increased in the CSF of euthymic bipolar patients with at least one manic/ hypomanic episode in the last year when compared with patients without a recent episode. ${ }^{[7]}$ Peripheral IL-1 $\beta$ concentrations also positively correlate with suicide risk in $\mathrm{BD}$ patients, ${ }^{[75]}$ and suicide risk is now known to be much higher when excitatory symptoms are present during relapses. ${ }^{[76,77]} \mathrm{IL}-1$ receptor antagonist (IL-1Ra) serum concentrations are higher in bipolar patients both in mania and partial remission, whereas they normalize when full remission is achieved. ${ }^{[78]}$ Several studies investigating serum concentrations of IL-8, as well as IL-2, IL-6 and their soluble receptors: IL-2 receptor (sIL-2R) and IL-6 receptor (sIL-6R), found that levels are higher in manic patients than in healthy controls. ${ }^{[79-81]}$ In particular, peripheral concentrations of IL-2, IL-6, and their receptors have been found to positively correlate with the severity of symptoms and tend to normalize following treatment and during remission. ${ }^{[58,72,79,80,82]}$ A recent study by Tsai's group ${ }^{[83]}$ also showed that concentrations of serum IL-6R reflected illness activity in a BD patient with manic relapses during a 63-week observation time. These findings, though, were only partially confirmed by meta-analyses that demonstrated increased peripheral expression of sIL-2R in manic patients, with just a trend toward the higher expression of IL-6 and sIL-6R. ${ }^{[69,70,84]}$ Levels of both TNF- $\alpha$ and its receptor, tumor necrosis factor receptor type 1 (sTNF-R1), are increased in manic BD patients compared to healthy controls and euthymic patients. ${ }^{[84]}$ Elevated TNF- $\alpha$ levels observed in mania do not normalize after treatment, suggesting that TNF- $\alpha$ may be considered as a trait marker of disease. ${ }^{[72]}$ This hypothesis is supported by the finding that serum TNF- $\alpha$ concentrations in $\mathrm{BD}$ patients are higher than in controls both in early ( $<3$ years) and late stages ( $>10$ years) of the disease, and that TNF- $\alpha$ levels are higher in late-stage than in early-stage patients. ${ }^{[85]}$ However, a study from Guloksuz et al. ${ }^{[86]}$ demonstrated by flow cytometry that measured levels of TNF- $\alpha$ are higher in lithium-treated, but not medication-free euthymic BD patients compared to healthy controls, suggesting that the persistently increased levels of TNF- $\alpha$ might result as an effect of lithium therapy rather than reflect a persistent pro-inflammatory inter-episodic status. It is interesting to note that TNF- $\alpha$ has been demonstrated to modulate inflammation and neurotransmission in brain regions regulating impulse control, like the prefrontal cortex and anterior cingulate cortex (ACC).$^{[87]}$ The expression of some TNF-related genes correlates with ACC activation and aggression in BD children and adolescents. ${ }^{[88]}$ Moreover, serum TNF- $\alpha$ concentrations correlate with deficits in executive functioning, that is, inhibitory control, in BD patients; ${ }^{[89]}$ inhibitory control is much more impaired in manic/mixed than in euthymic or depressed BD patients. ${ }^{[90]}$ Levels of sTNF-R1 positively correlate with elevated mood, being increased in manic states compared to depression, ${ }^{[11,92]}$ and are much higher in BD-I than in BD-II patients ${ }^{[68]}$ Plasma levels of sTNF-R1 also positively correlate with general disease gravity and psychotic features in $\mathrm{BD}$ patients. ${ }^{[93]}$

The alterations in the expression of TNF- $\alpha$ in BD are quite intriguing since this factor is involved in many processes, such as synaptic transmission, synaptic plasticity, neurodevelopment, neurotoxicity, and regulation of neuronal survival. ${ }^{[94,95]}$ Increased expression of TNF- $\alpha$ during acute mood episodes is thought to shift the balance between cellular survival and cellular death toward apoptosis, ${ }^{[96]}$ therefore playing a role in the neurodegeneration observed in chronic $\mathrm{BD}$ patients and possibly in cognitive impairment. ${ }^{[97]}$ Furthermore, TNF- $\alpha$ induces central recruitment of circulating monocytes during peripheral inflammation by cerebral microglia, ${ }^{[98]}$ which in turn produces more pro-inflammatory cytokines, sustaining the inflammatory status. ${ }^{[99]}$

C-reactive protein is a nonspecific acute-phase protein, synthesized by hepatocytes in response to IL-1 and IL-6 secretion during inflammatory processes. CRP levels in $\mathrm{BD}$ patients rise during both mania and depression and remain higher than in controls in partial and full remission of symptoms, ${ }^{[78,83,100]}$ suggesting a constant, nonspecific activation of immunomodulatory processes. Nevertheless, other studies have found increased levels of CRP only in manic bipolar patients and not in depressed or euthymic patients, ${ }^{[101]}$ and that 
the increase in CRP levels positively correlates with the severity of manic symptoms. ${ }^{[102,103]}$

The complement system is a part of the innate immune system. It consists of over 30 different proteins and its activation ultimately leads to a massive amplification of the immune response. Increased levels of complement factors C3, C4, and C6 have been found in BD patients during mania. ${ }^{[104]}$

Several studies have demonstrated an abnormal activation of T-cells in bipolar patients, regardless of the phase, ${ }^{[58]}$ whereas others have found an increase in T-cell proliferation and activation during manic states that normalized after full remission. ${ }^{[105,106]} \mathrm{A}$ recent study demonstrated an increased proportion of circulating monocytes in BD patients, ${ }^{[107]}$ and a correlation between a subcluster of monocyte proinflammatory gene (i.e. CCL2 and CCL7) expression and excitatory symptoms was found. ${ }^{[108]}$ Interestingly, total leukocyte counts are higher in mixed states than in pure manic states, and this difference appears to be due mainly to an increased number of neutrophils and monocytes. ${ }^{[109]}$

Oxidative stress is defined as the imbalance between oxidant and anti-oxidant agents, provoking macromolecular and cellular damage and ultimately inducing impairments in neuronal survival, plasticity, and signal transmission. ${ }^{[110]}$ Alterations in the oxidative status have been found to differ within mood states in BD patients. Peripheral levels of nitric oxide (NO), a powerful oxidant agent, are higher in BD patients, especially during mania, and also positively correlate with the number of lifetime manic episodes. ${ }^{[111,112]}$ When compared with euthymic subjects or healthy controls, manic patients show higher levels of thiobarbituric acid reactive substances (TBARS) and protein carbonyl content (PCC), peripheral markers of lipid peroxidation and oxidative damage to proteins, respectively. ${ }^{[113]}$ TBARS levels normalize after treatment with mood stabilizers and anti-psychotic drugs. ${ }^{[114]}$ Levels of superoxide dismutase, a main component of the anti-oxidant defense system, are also higher in BD patients during mania, suggesting a compensatory response to increased oxidative stress. ${ }^{[115]}$ The imbalance in the oxidative state of manic BD patients is normalized by lithium treatment. ${ }^{[116]}$

Arachidonic acid is one of the most abundant fatty acids in the brain and is a precursor in the production of prostaglandins (PG). PG are hormone-like lipid compounds, synthesized from AA by cyclooxygenase (COX) isoenzymes, and play crucial roles in the promotion of systemic inflammation. ${ }^{[17]}$ Protein and mRNA levels of COX isoform-2 (COX-2) and other AA signaling pathway enzymes, such as phospholipase A2 (PLA2) and membrane prostaglandin E synthase, are higher in the postmortem frontal cortex of bipolar patients than in healthy controls. ${ }^{[118]} \mathrm{A}$ recent study suggests that some of these alterations might be due to epigenetic mechanisms. ${ }^{[119]}$ Among other pro-inflammatory stimuli, COX-2 expression is induced by TNF- $\alpha,{ }^{[120,121]}$ the production of which has been found to be increased during manic relapses of BD as already described. Lamotrigine and valproic acid, two widely used mood stabilizing agents, decrease COX-2 expression in rat frontal cortex. ${ }^{[122,123]}$ Unlike lamotrigine, ${ }^{[124]}$ however, agents known to be effective in treating mania, such as lithium, carbamazepine, valproate, and the anti-psychotic drugs clozapine and olanzapine, also decrease AA turnover in rat brain, ${ }^{[125-135]}$ eventually modulating dopaminergic and glutamatergic transmission. ${ }^{[136-138]}$ On the other hand, the antidepressants fluoxetine and imipramine, but not bupropion, increase AA signaling and turnover in the rat brain. ${ }^{[139-141]}$ These findings are intriguing, considering that antidepressant treatment in bipolar patients often leads to a switch from a depressive to a manic/hypomanic state ${ }^{[142,143]}$ and that, among antidepressants, bupropion is the drug associated with the lowest risk of inducing switching. ${ }^{[144,145]}$ Taken together, these findings suggest that manic/hypomanic phases might be associated with a higher rate of AA signaling, an interesting hypothesis that would need more in-depth research. ${ }^{[146]}$ Novel neuroimaging techniques such as positron emission tomography with 11C-labeled fatty acids might help to better clarify the AA turnover and signaling cascade in the brain of BD patients and its role in the development of symptoms. ${ }^{[147]}$

Microglial cells are the resident macrophages of the central nervous system and play critical roles both in physiological and pathological functioning of the brain, as well as during neurodevelopment. ${ }^{[148]}$ One of the most important activities of microglial cells is to regulate inflammation within the CNS via the production of pro-inflammatory cytokines and free radicals, as well as anti-inflammatory components. ${ }^{[149]}$ Aberrant microglial cell number and function are involved in the pathophysiology of psychiatric disorders, including $\mathrm{BD},{ }^{[28,66,150-153]}$ possibly modulating GSK-3 $\beta /$ Wnt pathway activity through neuroinflammation. ${ }^{[67]}$ However, to date, little is known about direct correlations between excitatory symptoms and glial activity. ${ }^{[67]}$ During acute manic states, alterations in neuronal/glial interactions and glutamatergic transmission have been demonstrated by proton magnetic resonance spectroscopy. ${ }^{[154]}$ Some additional evidence on this issue has been provided by animal experiments. 
Mice lacking the alpha-2 isoform of $\mathrm{Na}^{+} / \mathrm{K}^{+}$-ATPase, also known as the sodium pump, show some manic-like behavior (i.e. hyperlocomotion), and hyperlocomotion is prevented by pretreatment with lithium. ${ }^{[155]} \mathrm{Na}^{+} / \mathrm{K}^{+}$-ATPase inhibitors, such as ouabain, have been extensively used in animal experiments to model BP. ${ }^{[156]}$ The alpha- 2 isoform is expressed exclusively in glial cells ${ }^{[157]}$ and is reduced in postmortem temporal cortex of $\mathrm{BD}$ patients. ${ }^{[158]}$

\section{Inflammation and excitatory symptoms in depression}

Markers of increased immune-inflammatory activity have been demonstrated in patients diagnosed with the major depressive disorder or unipolar depression (UD). These findings have been further confirmed by meta-analyses, ${ }^{[159,160]}$ but the studies included in the research, if considered individually, did not present homogeneous results. This might be explained by methodological differences in conducting the studies and/or by a variety of confounding factors, one of which might be the presence of some subthreshold excitatory symptoms in depressed patients such as mood lability, inner tension, irritability, racing and crowded thoughts, talkativeness, sleep disturbances, and psychomotor agitation. ${ }^{[161-163]}$ These symptoms are often misidentified in clinical practice, ${ }^{[164-166]}$ despite being present in around $40 \%$ of patients diagnosed with depression. ${ }^{[167,168]}$ In addition, about $20 \%$ of subjects initially diagnosed with the major depressive disorder and without lifetime manic symptoms develop excitatory features during the course of their disease. ${ }^{[169]}$

A recent study found significantly elevated baseline levels of CRP in patients diagnosed with UD that later developed excitatory symptoms compared to unipolar depressed patients who did not show manic symptoms over two years follow-up. ${ }^{[170]}$ A similar, but nonsignificant, trend toward higher levels of IL-6 and TNF- $\alpha$ was also observed. ${ }^{[170]}$ Both the presence of excitatory symptoms during the depression and high levels of serum cytokines before treatment are associated with a more severe course of the disease and poor response to antidepressants. ${ }^{[171-176]}$ It could be therefore hypothesized that an increased inflammatory status might be responsible, at least in part, for this evidence.

Excitatory symptoms are twice as common in bipolar depression than in UD, ${ }^{[165]}$ and patients diagnosed with major depression that also show psychomotor agitation are nearly three times more likely to undergo mood-switching than depressed patients without excitatory symptoms. ${ }^{[177]}$ This is consistent with the theory that agitated depression should be re-conceptualized as an "attenuated mixed state" belonging to bipolar-spectrum disorders. ${ }^{[171]}$

Until date, few studies have specifically focused on immune alterations during the bipolar depression. Higher levels of IL-1 $\beta$, IL-2, IL-6, IL-8, IL-10, TNF- $\alpha$, high-sensitivity CRP (hs-CRP), sIL-2R, sIL-6R, sTNF-R1, and IL-1Ra have been found in serum and/or plasma of depressed BD patients, ${ }^{[79,81,100,178]}$ although these findings were not completely confirmed in meta-analyses. ${ }^{[69,70,84]}$ Interestingly, some of these markers (i.e. sIL-R2, TNF- $\alpha$, and sTNF-R1) appear to be elevated during manic/ hypomanic phases as well..$^{[41]}$ Depressed BD patients also show alterations in oxidative stress markers and glial activity. ${ }^{[179]}$

Few studies have compared levels of inflammatory markers between BD and UD patients, and the results were mostly nonsignificant. However, a recent work from Bai et al..$^{[54]}$ found that bipolar patients show higher serum levels of sIL-6R, CRP, sTNF-R1, and monocyte chemotactic protein-1 (MCP1) than patients with different subtypes of UD, hinting that dysregulation of the immune system is more severe in BD than in UD.

\section{Inflammation in BD prodromes}

Excitatory symptoms, although quite nonspecific, are also frequent during the prodromal stages of $\mathrm{BD}$ in adolescents. ${ }^{[180]}$ These symptoms include mood swings, hyperactivity, sleep disturbances, irritability and aggressiveness, and anxiety. ${ }^{[181,182]}$ Cytokines are thought to interact with adrenal and gonadal hormones during adolescence, therefore influencing neurodevelopment and contributing to subsequent onset of psychiatric diseases; ${ }^{[183]}$ a role for a preexisting pro-inflammatory status in adolescents with high-risk of developing BD has been suggested. ${ }^{[184]}$ Recently, a prospective study demonstrated alterations in the immune state, such as increased inflammatory gene expression in monocytes during adolescence and increased levels of chemokine ligand 2 (CCL2, also known as MCP1), a marker of monocyte activation and migration, during young adulthood in the offspring of BD patients. ${ }^{[185]}$

\section{Inflammation in postpartum psychosis}

There's a general consensus that postpartum psychosis may often occur as a first episode of BD. ${ }^{[186,187]}$ Pregnancy in itself is considered a period of great modifications in the function of the immune system and immune activation has been observed during the postpartum period. ${ }^{[188,189]}$ A recent study found reduced levels of T-cells, increased levels of monocytes, and increased expression of monocyte genes in patients with first-onset postpartum psychosis. ${ }^{[190]}$ 


\section{EFFECT OF PHARMACOLOGICAL TREATMENT ON INFLAMMATORY MARKERS IN BD}

Mood stabilizing agents commonly used in the therapy of BD have been suggested to partially exert their activity via the regulation of the immune system and oxidative stress pathways. ${ }^{[191]}$ A number of studies have provided evidence supporting anti-inflammatory effects of lithium via different mechanisms. ${ }^{[192,193]}$ Lithium decreases the synthesis of pro-inflammatory enzymes and molecules (i.e. IL-1 $\beta$, TNF- $\alpha$, PG, NO, iNOS, COX-2 and PLA2), and regulates microglial activity in vitro. ${ }^{[194-199]}$ Similarly, lithium therapy shows some immunoregulatory activity in bipolar patients. It has been demonstrated to decrease the number and the activity of inflammatory cytokine-producing cells in BD patients ${ }^{[197,200]}$ and to reduce the synthesis of Th1 cytokines. ${ }^{[201]}$ Lithium also normalizes elevated levels of sIL-2R and sIL-26R in rapid-cycling BD patients. ${ }^{[202]}$

As mentioned earlier, valproic acid down-regulates the AA signaling cascade by inhibiting the synthesis of COX-1 and COX-2 in the rat brain. ${ }^{[203]}$ In addition, valproate and other antiepileptic drugs commonly used as mood-stabilizing agents, namely carbamazepine, lamotrigine, oxcarbazepine, and topiramate, significantly reduces the synthesis of a number of cytokines in vitro. ${ }^{[80,204,205]}$ Anti-psychotic drugs such as clozapine, quetiapine, risperidone, and ziprasidone also show some immunoregulatory effect by modulating the AA signaling cascade, cytokine and acute-phase protein synthesis, and microglial activation both in vitro and in vivo. ${ }^{[80,129,131,206-217]}$

\section{FUTURE DIRECTIONS}

Because of the converging evidence pointing to inflammatory dysregulation in the pathophysiology of psychiatric diseases, drugs specifically modulating the inflammatory response, such as acetylsalicylic acid and other nonsteroidal anti-inflammatory drugs (NSAIDs), omega-3 fatty acids, anti-TNF- $\alpha$ agents, minocycline, and $\mathrm{N}$-acetyl cysteine (NAC) have been investigated as new therapeutic options, with still controversial results. ${ }^{[3,218-221]}$ In particular, a randomized study proved the efficacy of adjunctive therapy with celecoxib, a nonsteroidal anti-inflammatory drug and a selective inhibitor of COX-2, in rapidly improving depressive symptoms in depression and mixed states of BDI and BDII patients. ${ }^{[222]}$ Another study found elevated levels of gene transcripts for prostaglandin D synthetase and prostaglandin D2 11-ketoreductase during depressive episodes in rapid-cycling BD patients; add-on treatment with celecoxib improved the severity of both depressive and manic/hypomanic phases, although more pronounced benefits were noted during depression. ${ }^{[223]}$

Tumor necrosis factor- $\alpha$ has been suggested to play a major role in mechanisms related to inflammation, neurodegeneration, and possibly neuroprogression of the disease in BD. Another study by Guloksuz et al. ${ }^{[224]}$ demonstrated a correlation between higher levels of TNF- $\alpha$ and a poor response to lithium treatment in BD patients. According to this evidence, TNF- $\alpha$ could be considered as a potential new target for the development of new drugs for BD therapy. ${ }^{[96,225]}$ Antagonism of IL-6 has also been hypothesized to be a novel therapeutic option to improve clinical outcome in $\mathrm{BD} .^{[226]}$

\section{CONCLUSION}

The literature reviewed provides evidence for a role of the inflammatory system in the pathophysiology of mood disorders. Nevertheless, a high rate of variability is observed among the different studies, especially those focused on evaluating the peripheral expression of inflammatory markers. There is a general consensus that BD patients show higher levels of cytokines in blood samples compared to healthy controls; however, data are inconsistent and comparisons between peripheral levels of inflammatory markers in manic/ hypomanic/mixed versus euthymic or depressed BD patients fail to converge to univocal conclusions. This may be explained by a number of reasons. First, studies differ in their methodology; some of them by assessing the expression of cytokines in serum, others in plasma, and yet others by evaluating cytokine production by in vitro stimulation of white blood cells from BD patients. Second, peripheral cytokine levels are influenced by several confounding factors, such as smoking status, body mass index, sleep disturbances, physical activity, and medications. Third, BD is highly heterogeneous in its manifestations so that a thorough selection of patients and classification of their mood state might be difficult. Finally, not all studies take into account factors such as age at onset and duration of illness, number of relapses, polarity of the last relapse, and the time intercurring from the last episode, which might be of importance in modifying the inflammatory status.

An enhanced pro-inflammatory status might partially explain the high rate of medical conditions often comorbid with BD, that is, cardiovascular, cerebrovascular, and metabolic diseases. Similarly, smoking, sleep impairment, and alcohol and substance abuse, the prevalence of which is high in BD patients, might contribute to the maintenance of a pro-inflammatory 
milieu. It is known that chronic inflammation induces a number of negative consequences in the brain, such as a high rate of tissue damage and structural changes in several areas, which in turn underlie functional impairments in neurotransmission. These alterations underpin some kind of both neuroanatomical and neurophysiological "vulnerability" in BD and represent the biological substrate for further relapses and progression of the illness.

Clinical observations indicate that $\mathrm{BD}$ is, in fact, a progressive disease, with many recurrences leading to more and more frequent and severe relapses, and associated with a reduction of inter-episode duration time, cognitive decline, and a worsening of the response to treatment, both pharmacological and psychotherapeutic. ${ }^{[227-232]}$ This ongoing process is likely to be exacerbated during acute phases of the illness, especially excitatory phases, and might be due, at least in part, to a stronger activation of the inflammatory system. ${ }^{[233,234]}$ Drugs modulating the immune system, or specifically some of its components, currently represent a promising field of investigation toward the development of add-on therapies aimed to achieve better clinical outcomes in the treatment of BD.

\section{Financial support and sponsorship}

This study was part of the FIRB project code RBFR12LD0W_002 and has been funded by a grant of the Italian Ministry of Research.

\section{Conflicts of interest}

There are no conflicts of interest.

\section{REFERENCES}

1. Miller AH, Manji HK. On redefining the role of the immune system in psychiatric disease. Biol Psychiatry 2006;60:796-8.

2. Najjar S, Pearlman DM, Alper K, Najjar A, Devinsky O. Neuroinflammation and psychiatric illness. $J$ Neuroinflammation 2013;10:43

3. Rosenblat JD, Cha DS, Mansur RB, McIntyre RS. Inflamed moods: a review of the interactions between inflammation and mood disorders. Prog Neuropsychopharmacol Biol Psychiatry 2014;53:23-34.

4. Cavanagh J, Mathias C. Inflammation and its relevance to psychiatry. Adv Psychiatr Treat 2008;14:248-55.

5. Yirmiya R. Depression in medical illness: the role of the immune system. West J Med 2000;173:333-6.

6. Kent S, Bluthe RM, Kelley KW, Dantzer R. Sickness behavior as a new target for drug development. Trends Pharmacol Sci 1992;13:24-8.

7. Dantzer R. Cytokine-induced sickness behavior: mechanisms and implications. Ann N Y Acad Sci 2001;933:222-34.

8. Dantzer R, O'Connor JC, Freund GG, Johnson RW, Kelley KW. From inflammation to sickness and depression: when the immune system subjugates the brain. Nat Rev Neurosci 2008;9:46-56.

9. Janssen HL, Brouwer JT, van der Mast RC, Schalm SW. Suicide associated with alfa-interferon therapy for chronic viral hepatitis. J Hepatol 1994;21:241-3.

10. Valentine AD, Meyers CA, Kling MA, Richelson E, Hauser P. Mood and cognitive side effects of interferon-alpha therapy. Semin Oncol 1998;25:39-47.

11. Hoyo-Becerra C, Schlaak JF, Hermann DM. Insights from interferon-alpha-related depression for the pathogenesis of depression associated with inflammation. Brain Behav Immun 2014;42:222-31.

12. Schaefer M, Engelbrecht MA, Gut O, Fiebich BL, Bauer J, Schmidt F, Grunze H, Lieb K. Interferon alpha (IFNalpha) and psychiatric syndromes: a review. Prog Neuropsychopharmacol Biol Psychiatry 2002;26:731-46.

13. Reichenberg A, Yirmiya R, Schuld A, Kraus T, Haack M, Morag A, Pollmacher T. Cytokine-associated emotional and cognitive disturbances in humans. Arch Gen Psychiatry 2001;58:445-52.

14. Maes M. Evidence for an immune response in major depression: a review and hypothesis. Prog Neuropsychopharmacol Biol Psychiatry 1995; 19:11-38.

15. Danner M, Kasl SV, Abramson JL, Vaccarino V. Association between depression and elevated C-reactive protein. Psychosom Med 2003;65:347-56.

16. Ford DE, Erlinger TP. Depression and C-reactive protein in US adults: data from the Third National Health and Nutrition Examination Survey. Arch Intern Med 2004;164:1010-4.

17. Kuo HK, Yen CJ, Chang CH, Kuo CK, Chen JH, Sorond F. Relation of $\mathrm{C}$-reactive protein to stroke, cognitive disorders, and depression in the general population: systematic review and meta-analysis. Lancet Neurol 2005;4:371-80.

18. Levine J, Barak Y, Chengappa KN, Rapoport A, Rebey M, Barak V. Cerebrospinal cytokine levels in patients with acute depression. Neuropsychobiology 1999;40:171-6.

19. Maes M. Major depression and activation of the inflammatory response system. Adv Exp Med Biol 1999;461:25-46.

20. Owen BM, Eccleston D, Ferrier IN, Young AH. Raised levels of plasma interleukin-1beta in major and postviral depression. Acta Psychiatr Scand 2001;103:226-8.

21. Frick LR, Williams K, Pittenger C. Microglial dysregulation in psychiatric disease. Clin Dev Immunol 2013;2013:608654.

22. Steiner J, Bogerts B, Sarnyai Z, Walter M, Gos T, Bernstein HG, Myint AM. Bridging the gap between the immune and glutamate hypotheses of schizophrenia and major depression: potential role of glial NMDA receptor modulators and impaired blood-brain barrier integrity. World J Biol Psychiatry 2012;13:482-92.

23. Tham MW, Woon PS, Sum MY, Lee TS, Sim K. White matter abnormalities in major depression: evidence from post-mortem, neuroimaging and genetic studies. J Affect Disord 2011;132:26-36.

24. Black CN, Bot M, Scheffer PG, Cuijpers P, Penninx BW. Is depression associated with increased oxidative stress? A systematic review and meta-analysis. Psychoneuroendocrinology 2015;51:164-75

25. Leonard B, Maes M. Mechanistic explanations how cell-mediated immune activation, inflammation and oxidative and nitrosative stress pathways and their sequels and concomitants play a role in the pathophysiology of unipolar depression. Neurosci Biobehav Rev 2012;36:764-85.

26. Lopresti AL, Maker GL, Hood SD, Drummond PD. A review of peripheral biomarkers in major depression: the potential of inflammatory and oxidative stress biomarkers. Prog Neuropsychopharmacol Biol Psychiatry 2014;48:102-11.

27. Michel TM, Pulschen D, Thome J. The role of oxidative stress in depressive disorders. Curr Pharm Des 2012;18:5890-9.

28. Beumer W, Gibney SM, Drexhage RC, Pont-Lezica L, Doorduin J, Klein HC, Steiner J, Connor TJ, Harkin A, Versnel MA, Drexhage HA. The immune theory of psychiatric diseases: a key role for activated microglia and circulating monocytes. $J$ Leukoc Biol 2012;92:959-75.

29. Roman A, Kreiner G, Nalepa I. Macrophages and depression-a misalliance or well-arranged marriage? Pharmacol Rep 2013;65:1663-72.

30. Smith RS. The macrophage theory of depression. Med Hypotheses 1991;35:298-306. 
31. Bazinet RP, Laye S. Polyunsaturated fatty acids and their metabolites in brain function and disease. Nat Rev Neurosci 2014;15:771-85.

32. Lieb J, Karmali R, Horrobin D. Elevated levels of prostaglandin E2 and thromboxane B2 in depression. Prostaglandins Leukot Med 1983;10:361-7.

33. Muller N, Myint AM, Schwarz MJ. The impact of neuroimmune dysregulation on neuroprotection and neurotoxicity in psychiatric disorders-Relation to drug treatment. Dialogues Clin Neurosci 2009;11:319-32.

34. Muller N, Myint AM, Schwarz MJ. Inflammatory biomarkers and depression. Neurotox Res 2011;19:308-18.

35. Nishino S, Ueno R, Ohishi K, Sakai T, Hayaishi O. Salivary prostaglandin concentrations: possible state indicators for major depression. Am J Psychiatry 1989;146:365-8.

36. Berk M, Williams LJ, Jacka FN, O'Neil A, Pasco JA, Moylan S, Allen NB, Stuart AL, Hayley AC, Byrne ML, Maes M. So depression is an inflammatory disease, but where does the inflammation come from? BMC Med 2013;11:200.

37. Leonard BE. The immune system, depression and the action of antidepressants. Prog Neuropsychopharmacol Biol Psychiatry 2001;25:767-80.

38. Maes M. Depression is an inflammatory disease, but cell-mediated immune activation is the key component of depression. Prog Neuropsychopharmacol Biol Psychiatry 2011;35:664-75

39. Raison CL, Capuron L, Miller AH. Cytokines sing the blues: inflammation and the pathogenesis of depression. Trends Immunol 2006;27:24-31

40. Sperner-Unterweger B, Kohl C, Fuchs D. Immune changes and neurotransmitters: possible interactions in depression? Prog Neuropsychopharmacol Biol Psychiatry 2014;48:268-76.

41. Goldstein BI, Kemp DE, Soczynska JK, McIntyre RS. Inflammation and the phenomenology, pathophysiology, comorbidity, and treatment of bipolar disorder: a systematic review of the literature. J Clin Psychiatry 2009;70:1078-90.

42. Basanth KK, Jacob R, Jacob KS. Mania associated with interferon alpha2b treatment. J Postgrad Med 2006;52:207-9.

43. Greenberg DB, Jonasch E, Gadd MA, Ryan BF, Everett JR, Sober AJ, Mihm MA, Tanabe KK, Ott M, Haluska FG. Adjuvant therapy of melanoma with interferon-alpha- $2 \mathrm{~b}$ is associated with mania and bipolar syndromes. Cancer 2000;89:356-62.

44. Mazzone L, Mugno D. Hypomanic mood in a child patient treated with interferon-alpha 2a: case report. Brain Dev 2007;29:666-9.

45. Strite $\mathrm{D}$, Valentine $\mathrm{AD}$, Meyers CA. Manic episodes in two patients treated with interferon alpha. $J$ Neuropsychiatry Clin Neurosci 1997;9:273-6

46. Constant A, Castera L, Dantzer R, Couzigou P, de Ledinghen V, Demotes-Mainard J, Henry C. Mood alterations during interferon-alfa therapy in patients with chronic hepatitis $\mathrm{C}$ : evidence for an overlap between manic/hypomanic and depressive symptoms. $J$ Clin Psychiatry 2005;66:1050-7.

47. Dell'Osso L, Pini S, Maggi L, Rucci P, Del Debbio A, Carlini M, Baldini A, Ferrari G, Manca E, Beverini E, Amore M, Scarallo V, Semeraro Q, Brunetto M, Bonino F, Maj M. Subthreshold mania as predictor of depression during interferon treatment in $\mathrm{HCV}+$ patients without current or lifetime psychiatric disorders. J Psychosom Res 2007;62:349-55.

48. Kilbourne AM, Cornelius JR, Han X, Pincus HA, Shad M, Salloum I, Conigliaro J, Haas GL. Burden of general medical conditions among individuals with bipolar disorder. Bipolar Disord 2004;6:368-73.

49. Kupfer DJ. The increasing medical burden in bipolar disorder. JAMA 2005;293:2528-30.

50. Sharma AN, Bauer IE, Sanches M, Galvez JF, Zunta-Soares GB, Quevedo J, Kapczinski F, Soares JC. Common biological mechanisms between bipolar disorder and type 2 diabetes: focus on inflammation. Prog Neuropsychopharmacol Biol Psychiatry 2014;54:289-98.

51. Leboyer M, Soreca I, Scott J, Frye M, Henry C, Tamouza R, Kupfer DJ. Can bipolar disorder be viewed as a multi-system inflammatory disease? J Affect Disord 2012;141:1-10.
52. Anderson G, Maes M. Bipolar disorder: role of immune-inflammatory cytokines, oxidative and nitrosative stress and tryptophan catabolites. Curr Psychiatry Rep 2015;17:8.

53. Andreazza AC, Kauer-Sant'anna M, Frey BN, Bond DJ, Kapczinski F, Young LT, Yatham LN. Oxidative stress markers in bipolar disorder: a meta-analysis. $J$ Affect Disord 2008;111:135-44.

54. Bai YM, Su TP, Li CT, Tsai SJ, Chen MH, Tu PC, Chiou WF Comparison of pro-inflammatory cytokines among patients with bipolar disorder and unipolar depression and normal controls. Bipolar Disord 2015;17:269-77.

55. Barbosa IG, Nogueira CR, Rocha NP, Queiroz AL, Vago JP, Tavares LP, Assis F, Fagundes CT, Huguet RB, Bauer ME, Teixeira AL, de Sousa LP. Altered intracellular signaling cascades in peripheral blood mononuclear cells from BD patients. JPsychiatr Res 2013;47:1949-54.

56. Barbosa IG, Rocha NP, Bauer ME, de Miranda AS, Huguet RB, Reis HJ, Zunszain PA, Horowitz MA, Pariante CM, Teixeira AL. Chemokines in bipolar disorder: trait or state? Eur Arch Psychiatry Clin Neurosci 2013;263:159-65.

57. Brambilla P, Bellani M, Isola M, Bergami A, Marinelli V, Dusi N, Rambaldelli G, Tansella M, Finardi AM, Martino G, Perlini C, Furlan R. Increased M1/decreased M2 signature and signs of Th1/ Th2 shift in chronic patients with bipolar disorder, but not in those with schizophrenia. Transl Psychiatry 2014;4:e406

58. Breunis MN, Kupka RW, Nolen WA, Suppes T, Denicoff KD, Leverich GS, Post RM, Drexhage HA. High numbers of circulating activated T cells and raised levels of serum IL-2 receptor in bipolar disorder. Biol Psychiatry 2003;53:157-65.

59. Brietzke E, Kauer-Sant'Anna M, Teixeira AL, Kapczinski F. Abnormalities in serum chemokine levels in euthymic patients with bipolar disorder. Brain Behav Immun 2009;23:1079-82.

60. Brown NC, Andreazza AC, Young LT. An updated meta-analysis of oxidative stress markers in bipolar disorder. Psychiatry Res 2014;218:61-8

61. Chung KH, Huang SH, Wu JY, Chen PH, Hsu JL, Tsai SY. The link between high-sensitivity $\mathrm{C}$-reactive protein and orbitofrontal cortex in euthymic bipolar disorder. Neuropsychobiology 2013;68:168-73.

62. Drexhage RC, Hoogenboezem TH, Versnel MA, Berghout A, Nolen WA, Drexhage HA. The activation of monocyte and T cell networks in patients with bipolar disorder. Brain Behav Immun 2011;25:1206-13.

63. Huang TL, Lin FC. High-sensitivity C-reactive protein levels in patients with major depressive disorder and bipolar mania. Pros Neuropsychopharmacol Biol Psychiatry 2007;31:370-2.

64. Padmos RC, Hillegers MH, Knijff EM, Vonk R, Bouvy A, Staal FJ, de Ridder D, Kupka RW, Nolen WA, Drexhage HA. A discriminating messenger RNA signature for bipolar disorder formed by an aberrant expression of inflammatory genes in monocytes. Arch Gen Psychiatry 2008;65:395-407.

65. Rao JS, Harry GJ, Rapoport SI, Kim HW. Increased excitotoxicity and neuroinflammatory markers in postmortem frontal cortex from bipolar disorder patients. Mol Psychiatry 2010;15:384-92.

66. Stertz L, Magalhaes PV, Kapczinski F. Is bipolar disorder an inflammatory condition? The relevance of microglial activation. Curr Opin Psychiatry 2013;26:19-26.

67. Watkins CC, Sawa A, Pomper MG. Glia and immune cell signaling in bipolar disorder: insights from neuropharmacology and molecular imaging to clinical application. Transl Psychiatry 2014;4:e350.

68. Bai YM, Su TP, Tsai SJ, Wen-Fei C, Li CT, Pei-Chi T, Mu-Hong C. Comparison of inflammatory cytokine levels among type I/type Il and manic/hypomanic/euthymic/depressive states of bipolar disorder. J Affect Disord 2014;166:187-92.

69. Modabbernia A, Taslimi S, Brietzke E, Ashrafi M. Cytokine alterations in bipolar disorder: a meta-analysis of 30 studies. Biol Psychiatry 2013;74:15-25

70. Munkholm K, Brauner JV, Kessing LV, Vinberg M. Cytokines in bipolar disorder vs. healthy control subjects: a systematic review and meta-analysis. J Psychiatr Res 2013;47:1119-33.

71. Borsini A, Zunszain PA, Thuret S, Pariante $\mathrm{CM}$. The role of 
inflammatory cytokines as key modulators of neurogenesis. Trends Neurosci 2015;38:145-57.

72. Kim YK, Jung HG, Myint AM, Kim H, Park SH. Imbalance between pro-inflammatory and anti-inflammatory cytokines in bipolar disorder. J Affect Disord 2007;104:91-5.

73. Kim YK, Myint AM, Lee BH, Han CS, Lee SW, Leonard BE, Steinbusch HW. T-helper types 1, 2, and 3 cytokine interactions in symptomatic manic patients. Psychiatry Res 2004;129:267-72.

74. Soderlund J, Olsson SK, Samuelsson M, Walther-Jallow L, Johansson C, Erhardt S, Landen M, Engberg G. Elevation of cerebrospinal fluid interleukin-1 $\beta$ in bipolar disorder. $J$ Psychiatry Neurosci 2011;36:114-8.

75. Monfrim X, Gazal M, De Leon PB, Quevedo L, Souza LD, Jansen K, Oses JP, Pinheiro RT, Silva RA, Lara DR, Ghisleni G, Spessato B, Kaster MP. Immune dysfunction in bipolar disorder and suicide risk: is there an association between peripheral corticotropin-releasing hormone and interleukin-1beta? Bipolar Disord 2014;16:741-7.

76. Sani G, Tondo L, Koukopoulos A, Reginaldi D, Kotzalidis GD, Koukopoulos AE, Manfredi G, Mazzarini L, Pacchiarotti I, Simonetti A, Ambrosi E, Angeletti G, Girardi P, Tatarelli R. Suicide in a large population of former psychiatric inpatients. Psychiatry Clin Neurosci 2011;65:286-95.

77. Shim IH, Woo YS, Bahk WM. Prevalence rates and clinical implications of bipolar disorder "with mixed features" as defined by DSM-5. J Affect Disord 2015;173:120-5.

78. Tsai SY, Chung KH, Wu JY, Kuo CJ, Lee HC, Huang SH. Inflammatory markers and their relationships with leptin and insulin from acute mania to full remission in bipolar disorder. J Affect Disord 2012;136:110-6.

79. Brietzke E, Stertz L, Fernandes BS, Kauer-Sant'anna M, Mascarenhas M, Escosteguy Vargas A, Chies JA, Kapczinski F. Comparison of cytokine levels in depressed, manic and euthymic patients with bipolar disorder. J Affect Disord 2009;116:214-7.

80. Maes M, Bosmans E, Calabrese J, Smith R, Meltzer HY. Interleukin-2 and interleukin- 6 in schizophrenia and mania: effects of neuroleptics and mood stabilizers. J Psychiatr Res 1995;29:141-52.

81. O'Brien SM, Scully P, Scott LV, Dinan TG. Cytokine profiles in bipolar affective disorder: focus on acutely ill patients. J Affect Disord 2006;90:263-7.

82. Tsai SY, Yang YY, Kuo CJ, Chen CC, Leu SJ. Effects of symptomatic severity on elevation of plasma soluble interleukin-2 receptor in bipolar mania. J Affect Disord 2001;64:185-93.

83. Tsai SY, Lee $\mathrm{CH}$, Huang $\mathrm{SH}$, Chung $\mathrm{KH}$, Chen PH. Soluble interleukin-6 receptor level reflecting the illness activity in bipolar disorder. Aust N Z J Psychiatry 2014;48:382-3.

84. Munkholm K, Vinberg M, Vedel Kessing L. Cytokines in bipolar disorder: a systematic review and meta-analysis. $J$ Affect Disord 2013;144:16-27.

85. Kauer-Sant'Anna M, Kapczinski F, Andreazza AC, Bond DJ, Lam RW, Young LT, Yatham LN. Brain-derived neurotrophic factor and inflammatory markers in patients with early- vs. late-stage bipolar disorder. Int J Neuropsychopharmacol 2009;12:447-58.

86. Guloksuz S, Cetin EA, Cetin T, Deniz G, Oral ET, Nutt DJ. Cytokine levels in euthymic bipolar patients. J Affect Disord 2010;126:458-62.

87. Jia D, Gao GD, Liu Y, He SM, Zhang XN, Zhang YF, Zhao MG. TNF-alpha involves in altered prefrontal synaptic transmission in mice with persistent inflammatory pain. Neurosci Lett 2007;415:1-5.

88. Barzman D, Eliassen J, McNamara R, Abonia P, Mossman D, Durling M, Adler C, DelBello M, Lin PI. Correlations of inflammatory gene pathways, corticolimbic functional activities, and aggression in pediatric bipolar disorder: a preliminary study. Psychiatry Res 2014:224:107-11.

89. Barbosa IG, Rocha NP, Huguet RB, Ferreira RA, Salgado JV, Carvalho LA, Pariante CM, Teixeira AL. Executive dysfunction in euthymic bipolar disorder patients and its association with plasma biomarkers. J Affect Disord 2012;137:151-5.

90. Ryan KA, Vederman AC, McFadden EM, Weldon AL, Kamali M, Langenecker SA, McInnis MG. Differential executive functioning performance by phase of bipolar disorder. Bipolar Disord
2012;14:527-36

91. Barbosa IG, Huguet RB, Mendonca VA, Sousa LP, Neves FS, Bauer ME, Teixeira AL. Increased plasma levels of soluble TNF receptor I in patients with bipolar disorder. Eur Arch Psychiatry Clin Neurosci 2011;261:139-43.

92. Hope S, Dieset I, Agartz I, Steen NE, Ueland T, Melle I, Aukrust P, Andreassen OA. Affective symptoms are associated with markers of inflammation and immune activation in bipolar disorders but not in schizophrenia. J Psychiatr Res 2011;45:1608-16.

93. Hope S, Ueland T, Steen NE, Dieset I, Lorentzen S, Berg AO, Agartz I, Aukrust P, Andreassen OA. Interleukin 1 receptor antagonist and soluble tumor necrosis factor receptor 1 are associated with general severity and psychotic symptoms in schizophrenia and bipolar disorder. Schizophr Res 2013;145:36-42.

94. Park KM, Bowers WJ. Tumor necrosis factor-alpha mediated signaling in neuronal homeostasis and dysfunction. Cell Signal 2010;22:977-83.

95. Stellwagen D, Malenka RC. Synaptic scaling mediated by glial TNF-alpha. Nature 2006;440:1054-9.

96. Brietzke E, Kapczinski F. TNF-alpha as a molecular target in bipolar disorder. Prog Neuropsychopharmacol Biol Psychiatry 2008;32:1355-61.

97. Doganavsargil-Baysal O, Cinemre B, Aksoy UM, Akbas H, Metin O, Fettahoglu C, Gokmen Z, Davran F. Levels of TNF-alpha, soluble TNF receptors (sTNFR1, sTNFR2), and cognition in bipolar disorder. Hum Psychopharmacol 2013;28:160-7.

98. D'Mello C, Le T, Swain MG. Cerebral microglia recruit monocytes into the brain in response to tumor necrosis factoralpha signaling during peripheral organ inflammation. J Neurosci 2009;29:2089-102.

99. Saijo K, Glass CK. Microglial cell origin and phenotypes in health and disease. Nat Rev Immunol 2011;11:775-87.

100. Tsai SY, Chung KH, Huang SH, Chen PH, Lee HC, Kuo CJ. Persistent inflammation and its relationship to leptin and insulin in phases of bipolar disorder from acute depression to full remission. Bipolar Disord 2014;16:800-8.

101. Cunha AB, Andreazza AC, Gomes FA, Frey BN, da Silveira LE, Goncalves CA, Kapczinski F. Investigation of serum high-sensitive $\mathrm{C}$-reactive protein levels across all mood states in bipolar disorder. Eur Arch Psychiatry Clin Neurosci 2008;258:300-4.

102. Dickerson F, Stallings C, Origoni A, Boronow J, Yolken R. Elevated serum levels of $\mathrm{C}$-reactive protein are associated with mania symptoms in outpatients with bipolar disorder. Prog Neuropsychopharmacol Biol Psychiatry 2007;31:952-5.

103. Lee SY, Chen SL, Chang YH, Chen PS, Huang SY, Tzeng NS, Wang YS, Wang LJ, Lee IH, Wang TY, Yeh TL, Yang YK, Hong JS, Lu RB. Inflammation's association with metabolic profiles before and after a twelve-week clinical trial in drug-naive patients with bipolar II disorder. PLoS One 2013;8:e66847.

104. Wadee AA, Kuschke RH, Wood LA, Berk M, Ichim L, Maes M. Serological observations in patients suffering from acute manic episodes. Hum Psychopharmacol 2002;17:175-9.

105. Liu HC, Yang YY, Chou YM, Chen KP, Shen WW, Leu SJ. Immunologic variables in acute mania of bipolar disorder. J Neuroimmunol 2004;150:116-22.

106. Tsai SY, Chen KP, Yang YY, Chen CC, Lee JC, Singh VK, Leu SJ. Activation of indices of cell-mediated immunity in bipolar mania. Biol Psychiatry 1999;45:989-94.

107. Barbosa IG, Rocha NP, Assis F, Vieira EL, Soares JC, Bauer ME, Teixeira AL. Monocyte and lymphocyte activation in bipolar disorder: a new piece in the puzzle of immune dysfunction in mood disorders. Int $J$ Neuropsychopharmacol 2014;18:pii: pyu021. doi: 10.1093/ijnp/pyu021.

108. Haarman BC, Riemersma-Van der Lek RF, Burger H, Netkova M, Drexhage RC, Bootsman F, Mesman E, Hillegers MH, Spijker AT, Hoencamp E, Drexhage HA, Nolen WA. Relationship between clinical features and inflammation-related monocyte gene expression in bipolar disorder - Towards a better understanding of psychoimmunological interactions. Bipolar Disord 2014;16:137-50.

109. Cassidy F, Wilson WH, Carroll BJ. Leukocytosis and hypoalbuminemia 
in mixed bipolar states: evidence for immune activation. Acta Psychiatr Scand 2002;105:60-4.

110. Mahadik SP, Evans D, Lal H. Oxidative stress and role of antioxidant and omega-3 essential fatty acid supplementation in schizophrenia. Prog Neuropsychopharmacol Biol Psychiatry 2001;25:463-93.

111. Gergerlioglu HS, Savas HA, Bulbul F, Selek S, Uz E, Yumru M. Changes in nitric oxide level and superoxide dismutase activity during antimanic treatment. Prog Neuropsychopharmacol Biol Psychiatry 2007;31:697-702.

112. Savas HA, Gergerlioglu HS, Armutcu F, Herken H, Yilmaz HR, Kocoglu E, Selek S, Tutkun H, Zoroglu SS, Akyol O. Elevated serum nitric oxide and superoxide dismutase in euthymic bipolar patients: impact of past episodes. World J Biol Psychiatry 2006;7:51-5.

113. Kapczinski F, Dal-Pizzol F, Teixeira AL, Magalhaes PV, Kauer-Sant'Anna M, Klamt F, Moreira JC, de Bittencourt Pasquali MA, Fries GR, Quevedo J, Gama CS, Post R. Peripheral biomarkers and illness activity in bipolar disorder. J Psychiatr Res 2011;45:156-61.

114. Tsai MC, Huang TL. Thiobarbituric acid reactive substances (TBARS) is a state biomarker of oxidative stress in bipolar patients in a manic phase. J Affect Disord 2015;173:22-6.

115. Kunz M, Gama CS, Andreazza AC, Salvador M, Cereser KM, Gomes FA, Belmonte-de-Abreu PS, Berk M, Kapczinski F. Elevated serum superoxide dismutase and thiobarbituric acid reactive substances in different phases of bipolar disorder and in schizophrenia. Prog Neuropsychopharmacol Biol Psychiatry 2008;32:1677-81

116. Machado-Vieira R, Andreazza AC, Viale CI, Zanatto V, Cereser V Jr, da Silva Vargas R, Kapczinski F, Portela LV, Souza DO, Salvador M, Gentil V. Oxidative stress parameters in unmedicated and treated bipolar subjects during initial manic episode: a possible role for lithium antioxidant effects. Neurosci Lett 2007;421:33-6.

117. Ricciotti E, FitzGerald GA. Prostaglandins and inflammation. Arterioscler Thromb Vasc Biol 2011;31:986-1000.

118. Kim HW, Rapoport SI, Rao JS. Altered arachidonic acid cascade enzymes in postmortem brain from bipolar disorder patients. Mol Psychiatry 2011;16:419-28.

119. Rao JS, Keleshian VL, Klein S, Rapoport SI. Epigenetic modifications in frontal cortex from Alzheimer's disease and bipolar disorder patients. Transl Psychiatry 2012;2:e132.

120. Moolwaney AS, Igwe OJ. Regulation of the cyclooxygenase-2 system by interleukin-1beta through mitogen-activated protein kinase signaling pathways: a comparative study of human neuroglioma and neuroblastoma cells. Brain Res Mol Brain Res 2005;137:202-12.

121. Munhoz CD, Garcia-Bueno B, Madrigal JL, Lepsch LB, Scavone C, Leza JC. Stress-induced neuroinflammation: mechanisms and new pharmacological targets. Braz J Med Biol Res 2008;41:1037-46.

122. Lee HJ, Ertley RN, Rapoport SI, Bazinet RP, Rao JS. Chronic administration of lamotrigine downregulates COX-2 mRNA and protein in rat frontal cortex. Neurochem Res 2008;33:861-6.

123. Rao JS, Bazinet RP, Rapoport SI, Lee HJ. Chronic treatment of rats with sodium valproate downregulates frontal cortex NF-kappaB DNA binding activity and COX-2 mRNA. Bipolar Disord 2007;9:513-20.

124. Lee HJ, Rao JS, Chang L, Rapoport SI, Bazinet RP. Chronic lamotrigine does not alter the turnover of arachidonic acid within brain phospholipids of the unanesthetized rat: implications for the treatment of bipolar disorder. Psychopharmacology (Berl) 2007;193:467-74

125. Basselin M, Kim HW, Chen M, Ma K, Rapoport SI, Murphy RC, Farias SE. Lithium modifies brain arachidonic and docosahexaenoic metabolism in rat lipopolysaccharide model of neuroinflammation. $J$ Lipid Res 2010;51:1049-56.

126. Bazinet RP, Weis MT, Rapoport SI, Rosenberger TA. Valproic acid selectively inhibits conversion of arachidonic acid to arachidonoyl-CoA by brain microsomal long-chain fatty acyl-CoA synthetases: relevance to bipolar disorder. Psychopharmacology (Berl) 2006;184:122-9.

127. Bazinet RP. Is the brain arachidonic acid cascade a common target of drugs used to manage bipolar disorder? Biochem Soc Trans
2009;37:1104-9.

128. Chang MC, Grange E, Rabin O, Bell JM, Allen DD, Rapoport SI. Lithium decreases turnover of arachidonate in several brain phospholipids. Neurosci Lett 1996;220:171-4.

129. Cheon Y, Park JY, Modi HR, Kim HW, Lee HJ, Chang L, Rao JS, Rapoport SI. Chronic olanzapine treatment decreases arachidonic acid turnover and prostaglandin E2 concentration in rat brain. J Neurochem 2011;119:364-76.

130. Ghelardoni S, Tomita YA, Bell JM, Rapoport SI, Bosetti F. Chronic carbamazepine selectively downregulates cytosolic phospholipase A2 expression and cyclooxygenase activity in rat brain. Biol Psychiatry 2004;56:248-54.

131. Kim HW, Cheon Y, Modi HR, Rapoport SI, Rao JS. Effects of chronic clozapine administration on markers of arachidonic acid cascade and synaptic integrity in rat brain. Psychopharmacology (Berl) 2012;222:663-74.

132. Modi HR, Taha AY, Kim HW, Chang L, Rapoport SI, Cheon Y. Chronic clozapine reduces rat brain arachidonic acid metabolism by reducing plasma arachidonic acid availability. $J$ Neurochem 2013;124:376-87.

133. Rao JS, Lee HJ, Rapoport SI, Bazinet RP. Mode of action of mood stabilizers: is the arachidonic acid cascade a common target? Mol Psychiatry 2008;13:585-96.

134. Rintala J, Seemann R, Chandrasekaran K, Rosenberger TA, Chang L, Contreras MA, Contreras MA, Rapoport SI, Chang MC. $85 \mathrm{kDa}$ cytosolic phospholipase A2 is a target for chronic lithium in rat brain. Neuroreport 1999;10:3887-90.

135. Rapoport SI. Lithium and the other mood stabilizers effective in bipolar disorder target the rat brain arachidonic acid cascade. ACS Chem Neurosci 2014;18:459-67.

136. Basselin M, Chang L, Bell JM, Rapoport SI. Chronic lithium chloride administration to unanesthetized rats attenuates brain dopamine D2-like receptor-initiated signaling via arachidonic acid. Neuropsychopharmacology 2005;30:1064-75.

137. Basselin M, Chang L, Chen M, Bell JM, Rapoport SI. Chronic carbamazepine administration attenuates dopamine D2-like receptor-initiated signaling via arachidonic acid in rat brain. Neurochem Res 2008;33:1373-83.

138. Ramadan E, Basselin M, Taha AY, Cheon Y, Chang L, Chen M, Rapoport SI. Chronic valproate treatment blocks D2-like receptor-mediated brain signaling via arachidonic acid in rats. Neuropharmacology 2011;61:1256-64.

139. Lee HJ, Rao JS, Ertley RN, Chang L, Rapoport SI, Bazinet RP. Chronic fluoxetine increases cytosolic phospholipase A (2) activity and arachidonic acid turnover in brain phospholipids of the unanesthetized rat. Psychopharmacology (Berl) 2007;190:103-15.

140. Lee HJ, Rao JS, Chang L, Rapoport SI, Kim HW. Chronic imipramine but not bupropion increases arachidonic acid signaling in rat brain: is this related to 'switching' in bipolar disorder? Mol Psychiatry 2010;15:602-14.

141. Rao JS, Ertley RN, Lee HJ, Rapoport SI, Bazinet RP. Chronic fluoxetine upregulates activity, protein and mRNA levels of cytosolic phospholipase A2 in rat frontal cortex. Pharmacogenomics $J$ 2006;6:413-20.

142. Boerlin HL, Gitlin MJ, Zoellner LA, Hammen CL. Bipolar depression and antidepressant-induced mania: a naturalistic study. $J$ Clin Psychiatry 1998;59:374-9.

143. Ghaemi SN, Hsu DJ, Soldani F, Goodwin FK. Antidepressants in bipolar disorder: the case for caution. Bipolar Disord 2003;5:421-33.

144. Leverich GS, Altshuler LL, Frye MA, Suppes T, McElroy SL, Keck PE Jr, Kupka RW, Denicoff KD, Nolen WA, Grunze H, Martinez MI, Post RM. Risk of switch in mood polarity to hypomania or mania in patients with bipolar depression during acute and continuation trials of venlafaxine, sertraline, and bupropion as adjuncts to mood stabilizers. Am J Psychiatry 2006;163:232-9.

145. Post RM, Altshuler LL, Leverich GS, Frye MA, Nolen WA, Kupka RW, Suppes T, McElroy S, Keck PE, Denicoff KD, Grunze H, Walden J, Kitchen CM, Mintz J. Mood switch in bipolar depression: comparison 
of adjunctive venlafaxine, bupropion and sertraline. Br J Psychiatry 2006;189:124-31.

146. Rapoport SI, Basselin M, Kim HW, Rao JS. Bipolar disorder and mechanisms of action of mood stabilizers. Brain Res Rev 2009;61:185-209.

147. Duncan RE, Bazinet RP. Brain arachidonic acid uptake and turnover: implications for signaling and bipolar disorder. Curr Opin Clin Nutr Metab Care 2010;13:130-8

148. Prinz M, Priller J. Microglia and brain macrophages in the molecular age: from origin to neuropsychiatric disease. Nat Rev Neurosci 2014; $15: 300-12$

149. Streit WJ, Mrak RE, Griffin WS. Microglia and neuroinflammation: a pathological perspective. J Neuroinflammation 2004;1:14.

150. Cotter DR, Pariante CM, Everall IP. Glial cell abnormalities in major psychiatric disorders: the evidence and implications. Brain Res Bull 2001;55:585-95.

151. Haarman BC, Riemersma-Van der Lek RF, de Groot JC, Ruhe HG, Klein HC, Zandstra TE, Burger H, Schoevers RA, de Vries EF, Drexhage HA, Nolen WA, Doorduin J. Neuroinflammation in bipolar disorder - A [(11) C]-(R)-PK11195 positron emission tomography study. Brain Behav Immun 2014;40:219-25.

152. Rajkowska G, Halaris A, Selemon LD. Reductions in neuronal and glial density characterize the dorsolateral prefrontal cortex in bipolar disorder. Biol Psychiatry 2001;49:741-52.

153. Rajkowska G. Postmortem studies in mood disorders indicate altered numbers of neurons and glial cells. Biol Psychiatry 2000;48:766-77.

154. Ongur D, Jensen JE, Prescot AP, Stork C, Lundy M, Cohen BM, Renshaw PF. Abnormal glutamatergic neurotransmission and neuronal-glial interactions in acute mania. Biol Psychiatry 2008;64:718-26.

155. Gao Y, Jhaveri M, Lei Z, Chaneb BL, Lingrel J, El-Mallakh RS. Glial-specific gene alterations associated with manic behaviors. Int J Bipolar Disord 2013;1:20.

156. El-Mallakh RS, El-Masri MA, Huff MO, Li XP, Decker S, Levy RS. Intracerebroventricular administration of ouabain as a model of mania in rats. Bipolar Disord 2003;5:362-5.

157. Juhaszova M, Blaustein MP. $\mathrm{Na}^{+}$pump low and high ouabain affinity alpha subunit isoforms are differently distributed in cells. Proc Natl Acad Sci U S A 1997;94:1800-5.

158. Rose AM, Mellett BJ, Valdes R Jr, Kleinman JE, Herman MM, $\mathrm{Li}$ R, el-Mallakh RS. Alpha 2 isoform of the $\mathrm{Na}, \mathrm{K}$-adenosine triphosphatase is reduced in temporal cortex of bipolar individuals. Biol Psychiatry 1998;44:892-7.

159. Dowlati Y, Herrmann N, Swardfager W, Liu H, Sham L, Reim EK, Lanctot KL. A meta-analysis of cytokines in major depression. Biol Psychiatry 2010;67:446-57.

160. Howren MB, Lamkin DM, Suls J. Associations of depression with C-reactive protein, IL-1, and IL-6: a meta-analysis. Psychosom Med 2009;71:171-86.

161. Benazzi F. Reviewing the diagnostic validity and utility of mixed depression (depressive mixed states). Eur Psychiatry 2008;23:40-8.

162. Koukopoulos A, Koukopoulos A. Agitated depression as a mixed state and the problem of melancholia. Psychiatr Clin North Am 1999:22:547-64.

163. Pacchiarotti I, Mazzarini L, Kotzalidis GD, Valenti M, Nivoli AM, Sani G, Torrent C, Murru A, Sanchez-Moreno J, Patrizi B, Girardi P, Vieta E, Colom F. Mania and depression. Mixed, not stirred. JAffect Disord 2011;133:105-13.

164. Hirschfeld RM. Bipolar depression: the real challenge. Eur Neuropsychopharmacol 2004;14 Suppl 2:S83-8.

165. Koukopoulos A, Ghaemi SN. The primacy of mania: a reconsideration of mood disorders. Eur Psychiatry 2009;24:125-34.

166. Koukopoulos A, Sani G. DSM-5 criteria for depression with mixed features: a farewell to mixed depression. Acta Psychiatr Scand 2014;129:4-16.

167. Angst J, Cui L, Swendsen J, Rothen S, Cravchik A, Kessler RC, Merikangas KR. Major depressive disorder with subthreshold bipolarity in the National Comorbidity Survey Replication. Am J Psychiatry 2010;167:1194-201.
168. Zimmermann P, Bruckl T, Nocon A, Pfister H, Lieb R, Wittchen HU, Holsboer F, Angst J. Heterogeneity of DSM-IV major depressive disorder as a consequence of subthreshold bipolarity. Arch Gen Psychiatry 2009;66:1341-52.

169. Boschloo L, Spijker AT, Hoencamp E, Kupka R, Nolen WA Schoevers RA, Penninx BW. Predictors of the onset of manic symptoms and a (hypo) manic episode in patients with major depressive disorder. PLoS One 2014;9:e106871.

170. Becking K, Boschloo L, Vogelzangs N, Haarman BC, Riemersma-van der Lek R, Penninx BW, Schoevers RA. The association between immune activation and manic symptoms in patients with a depressive disorder. Transl Psychiatry 2013;3:e314.

171. Akiskal HS, Benazzi F, Perugi G, Rihmer Z. Agitated "unipolar" depression re-conceptualized as a depressive mixed state: implications for the antidepressant-suicide controversy. $J$ Affect Disord 2005;85:245-58.

172. Angst J, Gamma A, Benazzi F, Ajdacic V, Eich D, Rossler W. Toward a re-definition of subthreshold bipolarity: epidemiology and proposed criteria for bipolar-II, minor bipolar disorders and hypomania. J Affect Disord 2003;73:133-46.

173. Eller T, Vasar V, Shlik J, Maron E. Pro-inflammatory cytokines and treatment response to escitalopram in major depressive disorder Prog Neuropsychopharmacol Biol Psychiatry 2008;32:445-50.

174. Ghaemi SN, Rosenquist KJ, Ko JY, Baldassano CF, Kontos NJ, Baldessarini RJ. Antidepressant treatment in bipolar versus unipolar depression. Am J Psychiatry 2004;161:163-5.

175. Lanquillon S, Krieg JC, Bening-Abu-Shach U, Vedder H. Cytokine production and treatment response in major depressive disorder Neuropsychopharmacology 2000;22:370-9.

176. Rihmer Z, Gonda X. Antidepressant-resistant depression and antidepressant-associated suicidal behaviour: the role of underlying bipolarity. Depress Res Treat 2011;2011:906462

177. Iwanami T, Maeshima H, Baba H, Satomura E, Namekawa Y, Shimano T, Suzuki T, Arai H. Psychomotor agitation in major depressive disorder is a predictive factor of mood-switching. J Affect Disord 2015;170:185-9.

178. Ortiz-Dominguez A, Hernandez ME, Berlanga C, Gutierrez-Mora D, Moreno J, Heinze G, Pavon L. Immune variations in bipolar disorder: phasic differences. Bipolar Disord 2007;9:596-602.

179. Andreazza AC, Cassini C, Rosa AR, Leite MC, de Almeida LM, Nardin P, Cunha AB, Cereser KM, Santin A, Gottfried C, Salvador M, Kapczinski F, Goncalves CA. Serum S100B and antioxidant enzymes in bipolar patients. J Psychiatr Res 2007;41:523-9.

180. Skjelstad DV, Malt UF, Holte A. Symptoms and signs of the initial prodrome of bipolar disorder: a systematic review. $J$ Affect Disord 2010;126:1-13

181. Egeland JA, Hostetter AM, Pauls DL, Sussex JN. Prodromal symptoms before onset of manic-depressive disorder suggested by first hospital admission histories. J Am Acad Child Adolesc Psychiatry 2000;39:1245-52.

182. Duffy A, Horrocks J, Doucette S, Keown-Stoneman C, McCloskey S, Grof P. Childhood anxiety: an early predictor of mood disorders in offspring of bipolar parents. J Affect Disord 2013;150:363-9.

183. Mills NT, Scott JG, Wray NR, Cohen-Woods S, Baune BT. Research review: the role of cytokines in depression in adolescents: a systematic review. J Child Psychol Psychiatry 2013;54:816-35.

184. Walker AJ, Kim Y, Price JB, Kale RP, McGillivray JA, Berk M, Tye SJ. Stress, inflammation, and cellular vulnerability during early stages of affective disorders: biomarker strategies and opportunities for prevention and intervention. Front Psychiatry 2014;5:34.

185. Mesman E, Hillegers MH, Ambree O, Arolt V, Nolen WA, Drexhage HA. Monocyte activation, brain-derived neurotrophic factor (BDNF), and S100B in bipolar offspring: a follow-up study from adolescence into adulthood. Bipolar Disord 2015;17:39-49.

186. Chaudron LH, Pies RW. The relationship between postpartum psychosis and bipolar disorder: a review. J Clin Psychiatry 2003;64:1284-92.

187. Sit D, Rothschild AJ, Wisner KL. A review of postpartum psychosis $J$ Womens Health (Larchmt) 2006;15:352-68. 
188. Buyon JP. The effects of pregnancy on autoimmune diseases. J Leukoc Biol 1998;63:281-7.

189. Ruiz-Irastorza G, Lima F, Alves J, Khamashta MA, Simpson J, Hughes GR, Buchanan NM. Increased rate of lupus flare during pregnancy and the puerperium: a prospective study of 78 pregnancies. Br J Rheumatol 1996;35:133-8.

190. Bergink V, Burgerhout KM, Weigelt K, Pop VJ, de Wit H, Drexhage RC, Kushner SA, Drexhage HA. Immune system dysregulation in first-onset postpartum psychosis. Biol Psychiatry 2013;73:1000-7.

191. Chiu CT, Wang Z, Hunsberger JG, Chuang DM. Therapeutic potential of mood stabilizers lithium and valproic acid: beyond bipolar disorder. Pharmacol Rev 2013;65:105-42.

192. Nassar A, Azab AN. Effects of Lithium on Inflammation. ACS Chem Neurosci 2014;5:451-8.

193. Quiroz JA, Machado-Vieira R, Zarate CA Jr, Manji HK. Novel insights into lithium's mechanism of action: neurotrophic and neuroprotective effects. Neuropsychobiology 2010;62:50-60.

194. Albayrak A, Halici Z, Polat B, Karakus E, Cadirci E, Bayir Y, Kunak S, Karcioglu SS, Yigit S, Unal D, Atamanalp SS. Protective effects of lithium: a new look at an old drug with potential antioxidative and anti-inflammatory effects in an animal model of sepsis. Int Immunopharmacol 2013;16:35-40.

195. Bosetti F, Rintala J, Seemann R, Rosenberger TA, Contreras MA, Rapoport SI, Chang MC. Chronic lithium downregulates cyclooxygenase-2 activity and prostaglandin E (2) concentration in rat brain. Mol Psychiatry 2002; 7:845-50.

196. Chang MC, Jones CR. Chronic lithium treatment decreases brain phospholipase A2 activity. Neurochem Res 1998;23:887-92.

197. Dong H, Zhang X, Dai X, Lu S, Gui B, Jin W, Zhang S, Zhang S, Qian Y. Lithium ameliorates lipopolysaccharide-induced microglial activation via inhibition of toll-like receptor 4 expression by activating the PI3K/Akt/FoxO1 pathway. J Neuroinflammation 2014;11:140.

198. Green HF, Nolan YM. GSK-3 mediates the release of IL-1beta, TNF-alpha and IL-10 from cortical glia. Neurochem Int 2012;61:666-71.

199. Nahman S, Belmaker RH, Azab AN. Effects of lithium on lipopolysaccharide-induced inflammation in rat primary glia cells. Innate Immun 2012;18:447-58

200. Boufidou F, Nikolaou C, Alevizos B, Liappas IA, Christodoulou GN. Cytokine production in bipolar affective disorder patients under lithium treatment. J Affect Disord 2004;82:309-13.

201. Rapaport MH, Manji HK. The effects of lithium on ex vivo cytokine production. Biol Psychiatry 2001;50:217-24.

202. Rapaport MH, Guylai L, Whybrow P. Immune parameters in rapid cycling bipolar patients before and after lithium treatment. J Psychiatr Res 1999;33:335-40.

203. Bosetti F, Weerasinghe GR, Rosenberger TA, Rapoport SI. Valproic acid down-regulates the conversion of arachidonic acid to eicosanoids via cyclooxygenase -1 and -2 in rat brain. J Neurochem 2003;85:690-6.

204. Himmerich H, Bartsch S, Hamer H, Mergl R, Schonherr J, Petersein C, Munzer A, Kirkby KC, Bauer K, Sack U. Impact of mood stabilizers and antiepileptic drugs on cytokine production in-vitro. $J$ Psychiatr Res 2013;47:1751-9.

205. Himmerich H, Bartsch S, Hamer H, Mergl R, Schonherr J, Petersein C, Munzer A, Kirkby KC, Bauer K, Sack U. Modulation of cytokine production by drugs with antiepileptic or mood stabilizer properties in anti-CD3- and anti-Cd40-stimulated blood in vitro. Oxid Med Cell Longev 2014;2014:806162

206. Al-Amin MM, Nasir Uddin MM, Mahmud Reza H. Effects of antipsychotics on the inflammatory response system of patients with schizophrenia in peripheral blood mononuclear cell cultures. Clin Psychopharmacol Neurosci 2013;11:144-51.

207. Bian Q, Kato T, Monji A, Hashioka S, Mizoguchi Y, Horikawa H, Kanba S. The effect of atypical antipsychotics, perospirone, ziprasidone and quetiapine on microglial activation induced by interferon-gamma. Prog Neuropsychopharmacol Biol Psychiatry 2008; $32: 42-8$
208. Chen ML, Wu S, Tsai TC, Wang LK, Tsai FM. Regulation of macrophage immune responses by antipsychotic drugs. Immunopharmacol Immunotoxicol 2013;35:573-80.

209. de Witte L, Tomasik J, Schwarz E, Guest PC, Rahmoune H, Kahn RS, Bahn S. Cytokine alterations in first-episode schizophrenia patients before and after antipsychotic treatment. Schizophr Res 2014; 154:23-9.

210. Hu X, Zhou H, Zhang D, Yang S, Qian L, Wu HM, Chen PS Wilson B, Gao HM, Lu RB, Hong JS. Clozapine protects dopaminergic neurons from inflammation-induced damage by inhibiting microglial overactivation. $J$ Neuroimmune Pharmacol 2012;7:187-201.

211. Kato T, Monji A, Hashioka S, Kanba S. Risperidone significantly inhibits interferon-gamma-induced microglial activation in vitro. Schizophr Res 2007;92:108-15.

212. Li H, Hong W, Zhang C, Wu Z, Wang Z, Yuan C, Li Z, Huang J, Lin Z, Fang Y. IL-23 and TGF-beta1 levels as potential predictive biomarkers in treatment of bipolar I disorder with acute manic episode. J Affect Disord 2015;174:361-6.

213. Maes M, Bosmans E, Kenis G, De Jong R, Smith RS, Meltzer HY. In vivo immunomodulatory effects of clozapine in schizophrenia. Schizophr Res 1997;26:221-5.

214. Maes M, Delange J, Ranjan R, Meltzer HY, Desnyder R, Cooremans W, Scharpe S. Acute phase proteins in schizophrenia, mania and major depression: modulation by psychotropic drugs. Psychiatry Res 1997;66:1-11.

215. Pollmacher T, Hinze-Selch D, Mullington J. Effects of clozapine on plasma cytokine and soluble cytokine receptor levels. $J$ Clin Psychopharmacol 1996;16:403-9.

216. Roge R, Moller BK, Andersen CR, Correll CU, Nielsen J. Immunomodulatory effects of clozapine and their clinical implications: what have we learned so far? Schizophr Res 2012:140:204-13.

217. Zhang XY, Zhou DF, Shen YC, Zhang PY, Zhang WF, Liang J, Chen da C, Xiu MH, Kosten TA, Kosten TR. Effects of risperidone and haloperidol on superoxide dismutase and nitric oxide in schizophrenia. Neuropharmacology 2012;62:1928-34.

218. Ayorech Z, Tracy DK, Baumeister D, Giaroli G. Taking the fuel out of the fire: evidence for the use of anti-inflammatory agents in the treatment of bipolar disorders. J Affect Disord 2015;174C: 467-78.

219. Berk M, Dean O, Drexhage H, McNeil JJ, Moylan S, O'Neil A, Davey CG, Sanna L, Maes M. Aspirin: a review of its neurobiological properties and therapeutic potential for mental illness. BMC Med 2013;11:74.

220. Magalhaes PV, Dean OM, Bush AI, Copolov DL, Malhi GS, Kohlmann K, Jeavons S, Schapkaitz I, Anderson-Hunt M, Berk M. A preliminary investigation on the efficacy of $\mathrm{N}$-acetyl cysteine for mania or hypomania. Aust N Z J Psychiatry 2013;47:564-8.

221. McNamara RK, Lotrich FE. Elevated immune-inflammatory signaling in mood disorders: a new therapeutic target? Expert Rev Neurother 2012;12:1143-61.

222. Nery FG, Monkul ES, Hatch JP, Fonseca M, Zunta-Soares GB Frey BN, Bowden CL, Soares JC. Celecoxib as an adjunct in the treatment of depressive or mixed episodes of bipolar disorder: a double-blind, randomized, placebo-controlled study. Hum Psychopharmacol 2008;23:87-94.

223. Begemann M, Sargin D, Rossner MJ, Bartels C, Theis F, Wichert SP, Stender N, Fischer B, Sperling S, Stawicki S, Wiedl A, Falkai P, Nave KA, Ehrenreich H. Episode-specific differential gene expression of peripheral blood mononuclear cells in rapid cycling supports novel treatment approaches. Mol Med 2008;14:546-52.

224. Guloksuz S, Altinbas K, Aktas Cetin E, Kenis G, Bilgic Gazioglu S, Deniz G, Oral ET, van Os J. Evidence for an association between tumor necrosis factor-alpha levels and lithium response. $J$ Affect Disord 2012;143:148-52

225. Soczynska JK, Kennedy SH, Goldstein BI, Lachowski A, Woldeyohannes HO, McIntyre RS. The effect of tumor necrosis factor antagonists on mood and mental health-associated quality of life: novel hypothesis-driven treatments for bipolar depression? 
Neurotoxicology 2009;30:497-521.

226. Brietzke E, Scheinberg M, Lafer B. Therapeutic potential of interleukin- 6 antagonism in bipolar disorder. Med Hypotheses 2011;76:21-3

227. Franchini L, Zanardi R, Smeraldi E, Gasperini M. Early onset of lithium prophylaxis as a predictor of good long-term outcome. Eur Arch Psychiatry Clin Neurosci 1999;249:227-30.

228. Kessing LV, Andersen PK, Mortensen PB. Predictors of recurrence in affective disorder. A case register study. $J$ Affect Disord 1998;49:101-8.

229. Rosa AR, Magalhaes PV, Czepielewski L, Sulzbach MV, Goi PD, Vieta E, Gama CS, Kapczinski F. Clinical staging in bipolar disorder: focus on cognition and functioning. $J$ Clin Psychiatry 2014; 75:e450-6.

230. Roy-Byrne P, Post RM, Uhde TW, Porcu T, Davis D. The longitudinal course of recurrent affective illness: life chart data from research patients at the NIMH. Acta Psychiatr Scand Suppl 1985;317:1-34.
231. Scott J, Paykel E, Morriss R, Bentall R, Kinderman P, Johnson T, Abbott R, Hayhurst H. Cognitive-behavioural therapy for severe and recurrent bipolar disorders: randomised controlled trial. $\mathrm{Br} J$ Psychiatry 2006;188:313-20.

232. Swann AC, Bowden CL, Calabrese JR, Dilsaver SC, Morris DD. Differential effect of number of previous episodes of affective disorder on response to lithium or divalproex in acute mania. Am J Psychiatry 1999;156:1264-6.

233. Berk M, Kapczinski F, Andreazza AC, Dean OM, Giorlando F, Maes M, Yucel M, Gama CS, Dodd S, Dean B, Magalhaes PV, Amminger P, McGorry P, Malhi GS. Pathways underlying neuroprogression in bipolar disorder: focus on inflammation, oxidative stress and neurotrophic factors. Neurosci Biobehav Rev 2011;35:804-17.

234. Berk M, Berk L, Dodd S, Cotton S, Macneil C, Daglas R, Conus P, Bechdolf A, Moylan S, Malhi GS. Stage managing bipolar disorder. Bipolar Disord 2014;16:471-7. 